\title{
Strategies for Adjustment to Loss and Grief among Selected Kenyan Orphaned Secondary School Students
}

\author{
Judith Anyango Owaa
}

PhD Student, Jaramogi Oginga Odinga University of Science and Technology

Dr Pamela Raburu

Department of Psychology, Jaramogi Oginga Odinga University of Science and Technology

*Dr Peter J.O. Aloka

Department of Psychology, Jaramogi Oginga Odinga University of Science and Technology, P.O. BOX 210, Bondo, 40601, Kenya jairopeteraloka@yahoo.com

Doi:10.5901/mjss.2015.v6n4s3p532

\section{Abstract}

The aim of the study was to investigate Strategies for adjustment to Loss and Grief among orphaned Kenyan secondary school students. The study was informed by Kübler-Ross Cycle model of loss and grief. Qualitative method research approach was used and with it, concurrent triangulation design was adopted. The target population consisted of 47 schools, 20 focus group discussion students, 10 personal interviews and 1,245 Form three orphaned students from public secondary schools in Kisumu Central Sub-County. A sample size of 20 adolescents that engaged in focus group discussion and 10 personal interviews from 15 secondary schools were sampled for the study using purposive sampling technique. Qualitative data wasanalyzed using thematic framework. Trustworthiness of qualitative data was ensured by analyzing the framework as fronted by Lincoln \&Guba. The study findings revealed that there were no statistically significant gender difference on adjustment to loss and grief. The study recommended that schools should introduce adapting-parenting model among teachers to take care of the orphaned students.

Keywords:Strategies; adjustment; Loss and Grief; orphans; secondary school; students

\section{Introduction}

Adolescence progression factors on its own are challenge enough to students. When coupled with adjustment to loss and grief of parent, sibling, peer or significant other, adolescents are disposed to crises as they try to maneuver both processes. As a developmental stage, adolescence primarily is a time of internal turmoil, and any additional turbulence may throw adolescents off balance of physical, emotional, cognitive and social maneuver of the prevalent progression changes. In the $21^{\text {st }}$ Century, death of parents has been the other crisis for adolescents. Socio-economic, cultural and emerging trends have created a paradigm shift that grieving adolescents seldom have someone to fall back to (Scharf \& Shulman, 2010). Most adolescents are struggling with loss and grief as schools have become academic-mean oriented and psychosocial support has been relegated to 'silence'. Unfortunately, the adolescent is still suffering under the weight of progression factors and grief. It therefore became pertinent that, more adolescents that are already battling with developmental crisis found themselves adjusting to loss and grief as well. The situation that was overwhelming showed that chances were high that adjusting to loss and grief of this magnitude could throw a student off balance (Okello, 2008). Therefore, the present study sought to bridge the gap by finding out possible strategies for adjustment to loss and grief among adolescent orphans.

Kisumu Central Sub-County of Kenya has 59 operational homes for orphans who can be traced to respective schools in the Central Sub-County (Victory Churches International, 2011). A total of 4,234 recorded orphans are sponsored and integrated into schools within the Municipality. According to Kisumu Sub-County Education Office, (2013), 2,841 semi and total orphans are sponsored in secondary schools by different church organizations and orphan homes around Kisumu County. Kisumu Children Trust, (2014) was one such orphan home that began in 1994, and presently 
houses more than 150 orphans while a total of 2,000 orphans that are school going, have passed though the same orphanage. Global Giving Foundation, (2012), was the other project that runs the only non-formal center in the slums of Manyatta- Kisumu.

A matron at a Kisumu Central Sub-County school, Kenya reported that twelve students who lost parents were unable to sleep for a period of time (Doughty, Pfefferbaum, Pfefferbaum, Dumont, Pynoos, Gurwitch \& Ndetei, 2006). The matron got to know when other peculiar tendencies like over clinging, insecurity, avoiding taking a bath and throwing tantrums were observed, that was also alluded to by (Biener \& Siegel, 2006). Another school's report in Kisumu Central Sub-County, indicated that a student who had been performing well dropped significantly after the father's death as explained by (Muchai, Ngari \& Mumiukha, 2014) in their pilot study. Foa, (2011) also explained that prolonged exposure to loss and grief may lead to Post Traumatic Stress Disorder which the present study suggests may interfere with progression factors. The same adolescents who are orphaned are also expected by the society to understand and excel in what they are doing thereby acting as solace to bereaved adult parents as a societal expectation as explained by (Owuor \& Mauta, 2011). Oblivious of the fact that these same adolescents are undergoing progression factors that are a crisis on its own, adolescents are left to manage their pain on their own. It leaves them with 'unfinished business'physically, emotionally,cognitively and even sociallyas noted by (Forbes, Phillips, Ryan\& Dahl, 2011). From an adolescents' point of view, loss of a parent, guardian or significant other is catastrophic especially if the deceased was their bread earner or worse still a role model. Adolescents would then ask themselves several unanswered questions which turn into rhetorics in their inside world as explained by (Grbac, 2008: Leek, 2011). These orphans are in the process of adjustment to loss and grief. However, it was not clear how the strategies that were put in place to enhance the process of adjustment to loss and grief. Thus, the study investigated Strategies for adjustment to Loss and Grief among orphaned Kenyan secondary school students.

\section{Theoretical Framework and Literature Review}

\subsection{Theoretical Framework}

The present study was informed by the Kübler-Ross Cycle model of loss and grief as cited by Freeman, (2005) and Worden, (2005). The model, developed by Kübler-Ross (1969) originally explained the experience of those dying from terminal illness. Presently, it has been widely used to explain the process and subsequent adjustment to grief more broadly (Bonanno, 2006). The grief cycle model was a useful perspective for understanding personal and other people's emotional reactions to personal trauma and change, irrespective of the cause. From Kübler-Ross (1969) model's perspective, adjusting to grief was not a linear process, it was considered to be fluid and as a result was believed that most people did not progress through the stages of the model in an orderly manner as indicated in (Shear, 2005). KüblerRoss,(1969) Cycle model, that was commonly referred to as the five stages of griefwas a concept which argued that; someone faced with the reality of impending death or an extreme, awful fatal experience, mostly processed a series of emotional stages (Worden, 2005). The model therefore had five distinct stages that an individual suffering from loss and grief was believed to pass through: Denial, Anger, Bargaining, Depression and Acceptance(Freeman, 2005). This theory informed the present study as it helped explain adjustment steps among students to loss and grief that may act as strategies to adjustment to loss and grief. .

\subsection{Literature Review}

Strategies for adjustment to loss and grief refers to the science and art of employing psychological therapeutic ability of one's innate power or group think so as to afford maximum support of knowledge, experience, emotion, social or practical help to an adopted situationMacauley, Onyango \& Niragira, (2012). The present study viewed strategies for adjustment to loss and grief as an adoption of a state of mind individually or with others where an adolescent would maneuver the crises of adjustment to loss and grief.Obrist, (2011) in a study of 208 students noted that teen pregnancy and subsequent school dropout were major issues that affected Kenyan secondary school students in maintenance of discipline and general wellness. The findings revealed a cultural situation that had no structure to support grieving children in Kenya. The study suggested that socio-cultural measures which were versatile by nature needed to be studied to help curb adolescent waste due to loss and grief. However, the study by Obrist, (2011) only gave a base line survey on adolescents and how they waste away due to pregnancy.

In a separate study by Owuor \& Mauta, (2011), on death as a natural phenomenon that affected adolescents most revealed that death of a parent was one of the major issues that disrupted growth and development of a child in the 
adolescent phase. Coupled with adolescent progression factors, death of parent or significant other was rated as the highest in social, emotional, cognitive and physical damage to an adolescent's growth. The study augmented that comprehensive care from all the stakeholders in the adolescents' environment was significant. The study suggested that, sustainable adaptation was wanting and needed to be strengthened in Kenya. The study also argued that loss and grief adaptation processes as stipulated in Kenyan cultural and contemporary societies eclipsed adolescents that are the interest of the present study.

Also, the reviewed study only suggested socio-cultural structures to be put in place to support children.

Pomeroy, (2011) in a study of 79 delinquents at a correction center in Kwazu Natal was interested in knowing which adolescent gender shows effects of progression factors most. The study findings revealed that, adolescent progression factors affected all adolescents in their cognitive (21\%), intellectual (14\%), emotional (43\%) and social (22\%) set ups which holistically affected an adolescent's self-concept. However, emotional and social progression factors affected female adolescents most while cognitive and intellectual affected the males most. The study therefore concluded that males are less concerned with their looks and feelings while females generally paid less attention to cognitive and intellectual stressors. The study recommended that adolescent emotional progression factors should be looked in to because they affect adolescents more. However, the study was based in South Africa at a correction centre and not in Kenyan schools.

A baseline study by Corcoran, Crusius \& Mussweiler, (2011) on group support and therapy training of literate and semiliterate ex-combatants in Burundi engaged 121 participants who experienced grief. The study findings revealed that, $90 \%$ of participants valued knowledge received, $70 \%$ learnt from experiences shared, $40 \%$ of participants had unfinished emotional issues, $98 \%$ accepted that to socialize was therapeutic while $61 \%$ of them favourably engaged in practical sessions as a means to therapy. The study concluded that group training needed to be carried to release more of the pent up feelings However, the reviewed study omitted discussion on pivot issues such as age of ex-combatants, nature of grief and span of time during postloss before therapy.

In a separate review, Leek, (2011) studied how gender was a factor in relation to students who went to the school counselor for therapy the study also looked at their partnerships and factors that influenced such involvement in North Carolina. Regression analysis revealed that, a significant number of female students sought therapy from the school counselor (63\%) compared to the male (19\%) representation. The study therefore concluded that more females are attended to by the school counselor than the male. The study recommended that male students should endavour to seek therapy as it is evident that it is helping the female students. However, the reviewed study focused on school counselor involvement with student in adjusting to loss and grief in North Carolina. Therefore, the present study filled the gap on how gender parity influenced adjustment to loss and grief for adolescents in Kisumu Central Sub-County.

Another study aimed at exploring the relationship between gender and social support strategies on life satisfaction for people with long-term mental illness that was carried out by Dumontheil, Apperly \& Blakemore, (2009). More males depended on males for help while females sought help from across the gender divide. These findings suggested that, females are flexible strengthening staff and friends' support by seeking help across the gender divide while the males are more reserved to their fellow males in seeking support. However, the reviewed study was based in Hong Kong engaging persons with long term mental illness while the present study filled the literature gap by engaging adolescents to find out their gender parities in adjustment to loss and grief.

Valkenburg \& Peter, (2011) carried out a survey on contemporary peer therapy goals. A sample of 53 participants was drawn from low income industrial workers community in Accra. The findings revealed that $59.3 \%$ were endeared to professional therapy, $7.2 \%$ to field approach, 11.1 to rehabilitation, $8 \& 7.1 \%$ to instructional and referral approach respectively. Community approach commanded $14.5 \%$ of the respondents. The study findings suggested that respondents were attracted to proffessional therapy followed by community approach. Important to note was the fact that peer therapy worked for the residents than any other category. However, the reviewed study was carried out with industrial workers and not student. The present study therefore, filled the literature gap by involving students who adjusted to loss and grief.

Hoy, (2012) conducted an observation of life and death among the Luo of Nyakach Plateau, Kenya. A group of 13 participants formed his baseline observation on how 'death ways' were part of the larger grieving process. The study findings revealed that from; family participation in bringing body to the mortician, wailing loudly as they accompanied the body down the sidewalk to the mortuary, being part of the funeral gathering that was a traditionally big observance involving several hundred people, in attendance for a two-day period, usually on the weekend following the death, bringing the body back home in the coffin they select (and was available from nearly any village market), taking the body back to the family compound for burial while wailing, most often right on their own ancestral land, cooking and serving food to visitors and mourners in the family compound were concepts that were quite embraced as part of the process of 
mourning the dead.

Asatsa, \& Gichuho, (2014) conducted an investigation in to the Batsotso mourning rituals in Kakamega County where observation and interview schedules were used to collect information from 67 mourners. The study findings showed that than $50 \%$ of the participants indicated that they understood the meaning of bonfire, washing the dead, burial at night, shaving of hair, burial of banana stem, beating the corpse, remarrying, speaking to the corpse, wailing, piercing the corpse and testimony. Less than $50 \%$ of the participants indicated that they understood the meaning of burial outside the compound. The study results indicated that majority of the Batsotso people understood the meaning of performing their mourning rituals. The study recommended that Batsotso people should practice mourning rituals that was seen to have therapeutic and psychological purpose as they helped the bereaved in coping with death by adjusting to loss and grief. In contrast, the investigation in to the Batsotso mourning rituals was based in Kakamega and not in Kisumu and was conducted with mourners and not students in school. The reviewed study also was purely qualitative with participants being members of the community while the present study used mixed methods.

Kamau, (2011) conducted research in Kiambu Municipality, Kenya with 50 purposefully selected bereaved adults (20 males and 30 females) who had experienced grief within the last five years and 30 practicing counsellors. The study finding was that adults perceived death in a very unique way. Adults in Kiambu were also aware of counselling services offered as intervention for loss and grief. Those who do not seek professional support seek social and religious support. The adult's perceptions to loss and grief range from psychological, physical, social and spiritual to philosophical. Further information revealed that counsellors offer loss and grief therapy. The findings also show through counsellors who responded that there was need for more support from the Health and Educational sectors in terms of adequate training facilities, relevant reading materials and in service courses where therapists could receive more skills and techniques. The study concluded that adults going through loss and grief are aware of counselling services available but have limited knowledge of its therapeutic value.

Mwiti, (2014) conducted reflections of 31 survivours of Nairobi Kenya's Westgate Terror Attack that left 72 people dead, hundreds wounded, thousands disoriented and others traumatized. The study findings on trauma indicated that those who directly experienced disaster suffered the greatest impact: the wounded, bereaved and those who suffered serious loss. The study also showed that the bereaved family members, witnesses of the event as well as others close enough felt their pain including the service providers. The findings also noted that rescue crews, media teams, the forces, security agents and other service providers often did not realize that they were affected. Counselors and Psychologists who were serving thousands of survivors also received Supervision to be able to cope with trauma. The study findings also showed unresolved traumatic stress, and if not effectively managed can lead to complications such as sleep disorders, appetite, and cause headaches. The study by Mwiti, (2014) was purely an in-depth interview of survivors' reflections of terror attack in Nairobi and not students in public secondary schools in Kisumu as was the case of the present study.

\section{Research Methodology}

\subsection{Research Design}

Concurrent Triangulation design helped in obtaining different but complementary data on the same topic, helping to best understand the research problem which eventually aided in bringing together differing strengths and non-overlapping weaknesses of qualitative methods (small sample, details, in-depth).The researcher adopted this design for this study because the qualitative aspect was adopted to explore the participant experiences and feelings on strategies for adjustment to loss and grief.

\subsection{Study Participants}

Target population for the present study comprised of 1245 Form three partially or totally orphaned students in public secondary schools in Kisumu Central Sub-County.A sample of 20 partial or total orphaned students wasselected from the sampled schools for focus group discussion while 10 other partial or total orphaned students was selected for personal interviews using purposive sampling technique. According to Lucas (2013), purposive sampling technique is primarily used in qualitative studies and was defined as selecting units (e.g., individuals, groups of individuals, institutions) based on specific purposes associated with answering a research study's questions. 


\subsection{Research Instruments}

Qualitative interview is a commonly used data collection method in research. It is conducted to elicit information that cannot be observed, and to get the feelings, thoughts, and the meanings that people attach to events(Babbie, 2007). Interview process-allows the researcher to observe and ask questions, thus providing opportunity to look at issues as if through the eyes of the participants (Sagoe, 2012). Lucas (2013) contends that semi-structured interviewing is more appropriate when one particularly intends to pursue a specific issue. In depth-interviewing was employed in the present study because it enabled the researcher to understand and interpret social reality through meanings that the respondents attached to their career experiences (Punch, 2010). The approach was viewed as suitable for reaching an understanding of meanings an individual attributes to some aspects of personal experiences and the sense of self (Punch, 2010). It was also suitable for the present study where researcher needed to get 10 adolescent's views on adolescents adjusting to loss in the presence of progression factors. Lucas (2013) described the importance of a researcher's voice as a tool to convey trustworthiness and genuinenessthereby conveying complete objectivity and credibility. It encourages researcher's focus, balanced understanding and depicting work authentically in all its complexity.All the interviews were audio-taped and transcribed verbatim for analysis by the researcher to allow for immersion in the data and to maintain coherence and connections in the content (Oso \& Onen (2009).

The present study also used Focus Group Discussion which is a form of qualitative research method that involves construction and reconstruction of knowledge (Sagoe, 2012). It is a flexible interactive and generative tool that explores meanings and language in depth (Rushkoff, 2005). Focus Group Discussion allows participants to feel their prevailing concerns from another person's point of view through reflections, paraphrasing and sharing thereby deriving strength to face their own (Grbac, 2008;Dorn \& Biro, 2011). Focus Group Discussion was employed in the present study because it enabled researcher to understand and interpret social realities through meanings and emotions that the respondents attached to their life experiences (Punch, 2010). In the present study, there were 5 focus group discussions; 1 for boys only, 1 for girls only and 3 for mixed school students and a moderator that was appointed in each of the groups as advised by (Morgan, 2007).

\subsection{Data Collection Procedures}

The researcher proceeded to collect data from selected respondents after receiving permission from Board of Post Graduate Studies of Jaramogi Oginga Odinga University of Science and Technology (JOOUST), National Council for Science and Technology Innovation (NACOSTI), sampled schools and participants. The researcher then did the following: developed questionnaires, conducted interview schedule for data collection, secured an authorization before embarking on study. Qualitative data was collected using 10 personal interviews and focus group discussions that were conducted with 20 semi and total orphans.

\subsection{Data Analysis}

Data was analyzedqualitatively. Qualitative data was analyzed using the thematic framework.Qualitative data analysis focused on review of all information to gain a sense of the overall data (Mason, 2010). Denzin \& Lincoln, (2011) also noted that, qualitative data analysis involved such processes as data reduction, display, conclusion drawing and verification. Denzin \& Lincoln, (2011) added that qualitative data analysis involved developing a detailed description of each case and situating the case within its context. In the present study, raw data that was produced from 20 tape recorded views and 10 personal interviews that were transcribed and read over and over so as to check for any incomplete, inconsistent or irrelevant data (Mason, 2010). Transcriptions were analyzed thematically using the process described by Creswell \& Plano-Clark, (2011) in their deliberations; the researcher (1) read through the transcribed interview many times, make important notes and brainstormed, (2) the content was summarized, and organized based on reflections, quotations and direct illustrations of respondents. The resultant themes were related to adolescence factors that respondents perceived to have influenced them in to or not in to adjustment to loss and grief; (3) the researcher then examined and alignedcoded data to research questions. (4) Finally, coded combinations were facilitated to study, sorted, compared and synthesized large amounts of data. Lastly (5), when the interpretations were put together, the researcher went through data to perform weighting, ordering and connecting of data parts. Maree, (2012). 


\section{Findings and Discussion}

The study investigated Strategies for adjustment to loss and grief among orphaned Kenyan secondary school students. Qualitative findings revealed that strategies of adjustment to loss and grief were; engaging on positive thinking, seeking peer therapy and support, seeking professional guidance and counselling services, engaging in group therapy, involvement in letter writing therapy, engaging in journaling therapy, reflections of past events, adoption of grandma's philosophy and engaging in self disclosure. However, 10 independent interviews with orphans gave the present research reflections of adolescents who were managing or had managed their loss and grief and were therefore acting as role models or were exemplary at school and in the community. The present study noted what worked for the respondents as strategies.

Positive thinking as a strategy refers to a mental and emotional attitude that focuses on the bright side of life and expects positive results. It is employed by a positive person who anticipates happiness, health and success, and believes he or she can overcome any obstacle and difficulty. This notion in life is not accepted by everyone. Some consider it as nonsense, yet there were a growing number of people, who accept positive thinking as a fact, and believe in its effectiveness (Berk, 2009). Respondents used positive thinking as a strategy for adjustment to loss and grief by adopting the attitude of positive thinking in managing their loss and grief. In the present study, two respondents of personal interviewees were role models in their respective schools and were orphans since they were age six and nine respectively. However, they had strategies for adjustment to loss and grief as they explained in the excerpt;

I decided to develop a positive attitude towards myself, I told myself that my uncle was good enough, now that mom and dad were gone...so far he helps me ....we talk a lot and he encourages me to soldier on...[A3]

Respondents decided to occupy their minds with positive thoughts and hope concerning their lives. Instead of despair, they were anticipating the very best in life. Respondents had learnt to focus on their growth and development and not to negatively dwell on their loss. It was therefore manifested in their overall behavior and character that had created a good impression, and consequently earned them the position of school head girl and role model respectively. Obrist, (2011)agreed that socio-cultural measures which were versatile by nature needed to be studied to help curb adolescent waste due to loss and grief. Andrea \& Salovey, (2006) also echoed the same when they said that adolescents developed internal building blocks (skills) that helped them cope with loss and grief.

Peer therapy refers to support that comes from age mates, workmates or persons for which there is a commonality of factors. Peer therapy occurs when people provide knowledge, experience, emotional, social or practical help to each other (Corey, 2005). It operates within the realms of trained supporters and can take a variety of forms. Peer therapy can be summed as help that equals give each other as support on a reciprocal basis. It was reported that participants used peer therapy as a strategy to overcome loss and grief. One such case was an artist who learnt through his peers to express himself in what he knew how to do best. He began by painting how his parents died. Lately, he narrated how art had helped him expend his pain of loss and now he drew contemporary issues in life. He augmented that with art, he had succeeded in beating any form of grief for he put his pain to pen and paper as she explained;

...my friends taught me to talk in drawings...art is real and I am forever grateful to my childhood friends who taught me how to express myself through drawings...I relieve myself of any form of stressful feelings...[A9]

The respondent learnt how to go round her pain with gains. She made her friends for whom they shared the same loss her 'talk mates.' Art became a medium of expressing her loss and a strategy for adjustment to loss. Aarhus, (2012) agreed that art is a powerful means of communication and expression of how an individual felt about an issue. Mwiti, (2014) also agreed that children spoke volumes on what they saw during post election violence through drawing, painting and encouragement from fellow children.

Professional guidance and counselling refers to services by a trained and licensed professional. Therapists are trained that any information shared is held in confidence under therapy guidelines. Professional therapy is unique to each person's individual needs, which the therapist and client work together to identify (Corey, 2005). The process therefore seeks to help people become more empowered to see new possibilities and find peace for living healthier and happier lives in all areas be it personal life, relationships, work, education and service. A male respondent was an only child to a single mother. He weathered the jeer at school about the mystery surrounding his paternity when he was in upper primary and later in secondary school as he narrated; 
The respondents seemed to have successfully adapted to his single parenthood status thanks to professional counselling. The respondent sounded fairly adjusted to his loss and grief and was ready to be there for others. On the contrary, Pomeroy, (2011) noted that adjustment to loss and grief was largely gender based and on specific issues that appealed to either gender. However, Angela, (2014) agreed that professional guidance and counselling allowed individuals to transform from irrationality back to rational thinking.

Group therapy refers to one or more therapists working with several clients that had a commonality of crisis for hybrid innate growth at the same time. Group therapy brings together a group of people irrespective of gender or race to share and learn from their experiences (Forsyth, 2010). The adolescent respondent was obese, hardworking in school, a sportsman and partially orphaned. He perceived that he had losses upon losses to grieve over until he accidentally chanced on overweight adolescents like him at a tournament. He felt better. Later that holiday, he joined a group of youths that were overweight and he even learnt how to tone down.

\title{
....adolescence is trouble enough; it becomes a nightmare when physique is also questionable...group therapy made me know I was not alone in this and was glad when it worked... [A7]
}

The respondent seemed to have found hope in his group of friends. He once again derived meaning in everything that he did because the group accepted him and communicated that acceptance. Cooney, (2010) agreed that acceptance of physical features was done better in groups and the lesson learn was permanent. Charmaz, (2006) also concurred that group therapy allowed individuals to reflect, reconstruct and accept self. However, Engler, (2008) cautioned that much as group therapy was good, care needed to be taken so that introverts are not left behind as therapist moved on with extroverts only thinking he has everybody. Corcoran et.al, (2011) also added that group training needed to be carried to release more of the pent up feelings. The study discussed letter writing therapy.

Letter writing is a form of expressive healing that uses the art of writing and processing the written word as therapy. Writing therapy exposes writer to his own feelings explicitly, thereby gradually coming to terms with his feelings that could otherwise cause emotional trauma (Friedkin \& Johnsen, 2011). Therapeutic writing can take place individually or in a group and it can be administered in person, with a therapist or remotely through mailing or the Internet. The respondent was an ' $A$ ' student since form 1 , he was a total orphan that lived with grandfather. Letter writing allowed the adolescent to relieve the anger of having lost parents early in life as he narrated;

\begin{abstract}
...Initially, I emptied my pain and anguish in letters to mom and dad...before Irealized, the tears grew lesser by the day and instead of writing in pain.Later, I developed excellent writing skills...my expressions became better and my grades too. Today I look back with joy that I chose to write and not to lament...am top of our class always...I harvest gifts on academic days... [A5]
\end{abstract}

The respondent has feelings of joy and looks back with gratitude. The alternative that he chose to embrace as a source of adjustment to loss and grief was of great benefit and he intimated that he had no regrets. Santrock, (2014) agreed that adolescents exude confidence and experience a high self esteem when they can express themselves excellently using martial arts and other developed skills. Deem, (2007) added that adolescents developed faster when appreciated than when they are constantly pinned down with errors. The study discussed engaging in journaling therapy.

Journaling therapy is keeping a personal record that details events and your feelings in relation to the very events. It is mainly an individual's effort to relieve events and forms of pain, joy, memorable events just like they occurred. Journaling therapy is a practiced form of self-help through writing also known as keeping a personal diary, where the writer records their most meaningful thoughts and feelings (Genga, 2012). One individual benefits when the act of writing puts a powerful brake on the torment of endlessly repeating troubled thoughts to which everyone is prone. It has powerful reflections because the writer is able to read his own mind and perceive experiences more clearly. The result may be a feeling of relief from tension. Being an introvert, a total orphan and was average in class, the respondent found journaling effective. Nature had it that he talked less so he found it easy to slip and get lost in journaling as he mentioned in the excerpt;

...I discovered that I could get lost in my personal records of all that happened in the day...before long, I derived strength from reading what I had written. Reading back what I had written earlier made me realize that I came across crises but also found ways of getting out of the same crises on my own. Reading my own writing became a powerful source of strength not only to self but I found myself helping others too...[A8] 
The adolescent respondent seemed to be happy at the result of his introvert escape route. He found solace in reading what he had written as a way of pouring out his emotions. In his safe haven, he managed to secure a strategy that helped him to adjust to loss and grief as well as gaining confidence in his class work. Valkenburg \& Peter, (2011) agreed that putting down one's thought processes and later reading them was a form of adjustment to loss and grief because it was like listening to one's self double. Pelt, (2005) agreed that the greatest communicators are the ones who put their ideas down on paper.

Reflection is the art of looking back on past events in your life and thinking about them, comparing and contrasting them with your current life. It would also mean allowing a therapist to listen to your conversation with an aim of giving them to you by summarizing major points and clarifying what you are feeling (Graham, 2005). In doing so you are allowing the client to explore their own feelings and actions without making them defensive because you are not telling them what to do but merely redescribing what they are saying. Reflection makes a client feel they are heard and understood. A respondent that was well behaved, obedient, partially orphaned and had a big inner world narrated as she relieved in her excerpt;

\begin{abstract}
...severally I caught myself having said the wrong thing and I chose to mend my thought process and not to believe my fallacy. Friends too helped me as they said what I told them and I could see where I erred...the most powerful was my own reflections on how I had handled issues in the past ... it's been a stronghold for growth while adjusting to loss and grief...[A10]
\end{abstract}

The respondent's reflections have been her biggest leap to healing. She also learnt that the art of loss made her learn how to reflect on what happened to her with her friends. Through reflection she got a second chance to listen to what she had said from the words of someone else. The process allowed her to know herself better and thereby gain strength to manage her loss. Hoy, (2012) agreed that reflections about the death of a significant other were forms of adjustment to loss. Corey, (2005) also agreed that to reflect was to renew one's level of adjustment to loss and grief and to progress positively in bereavement.

Self disclosure is communication through which one person reveals himself or herself to another. It comprises everything an individual chooses to tell the other person about himself, making him known (Ziv-Beiman, 2013). The information can be descriptive or evaluative and can include thoughts, feelings, aspirations, goals, failures, successes, fears, dreams as well as one's likes, dislikes, and favorites. The present study respondents found strategy for adjustment both to their developmental issues and loss when persons like them disclosed themselves.Self disclosure works well as a strategy if the person disclosing was once in a crisis, had overcome and now has a success story to share. The intention was to lift the person who needed help so that he could find his way to recovery. Two respondents were beneficiaries of self disclosure and because they found help when others disclosed to them, they too have made it a point to disclose to anyone who needed a shot in the arm.

\begin{abstract}
...it was my friend in school who found me crying and shouting my mother's name...she sat there till I stopped crying, I shared my pain and she told me her story that she also lost both parents but has learnt to beat those who have parents in academics...she promised to teach me how to work hard and to date I have no regrets. [A1]
\end{abstract}

\begin{abstract}
...I thought I had issues with my $82 \mathrm{~kg}$ until I met this $113 \mathrm{~kg}$ adolescent and was partially orphaned like me. He was happy, not bothered by his weight and seemed to carry it around with ease. He settled on the same table with me for tea and I inquired how he manages to keep his head held high...I found healing as he taught me that I am the one to construct my self-concept...if I think am ugly...so be it. I tried and it worked. [A7]
\end{abstract}

The adolescents seemed to have listened to other respondents with success stories of adjustment to loss and grief which made them to get in to the path of adjustment too. Klass, (2006) agreed that listening to individuals who have been through loss and are adjusted gives hope to grieving persons. Miesbach, (2013) also concurred that self disclosure can be an instant healing to another person struggling with loss and grief. Although Asatsa, \& Gichuho, (2014) noted that even in the presence of self disclosure, practicing mourning rituals was seen to have therapeutic effect on mourners than any other intervention.

\title{
5. Concluding Remarks
}

The study investigated Strategies for adjustment to loss and grief. The study findings revealed that adolescents developed strategies of adjustment to loss and grief and that they were strategies that adolescents could possibly employ 
to adjust to loss and grief such as; engaging on positive thinking, seeking peer therapy and support, seeking professional guidance and counselling services, engaging in group therapy, involvement in letter writing therapy, engaging in journaling therapy, reflections of past events, adoption of grandma's philosophy and engaging in self disclosure. The study reported that there were as many strategies for adjustment to loss and grief as were the adolescents that were aiming at adjustment to loss and grief in the presence of progression factors. It meant that orphaned adolescents are capable of adjustment to loss and grief which depended on their personality and gender.

Based on the findings of the study there are implications: Schools should strengthen peer counselling among students in their respective schools. This is because the study found out that most orphaned students sought peer support from fellow students. Secondly, the Ministry of Education should train special teachers on how to provide therapy to adolescents who need therapy, like those under the influence of progression factors while trying to adjust to loss and grief. This is because professionalism in therapy may help teachers in identifying and conducting therapy so that students can concentrate on the cardinal objective of academic excellence.

\section{References}

Aarhus, P. (2012). The Mungiki, the Taliban and Me: Recollections of Mathare youths. Retrieved from http//www.vice.com/read/themungiki-the-taliban-and-me- on 29th January, 2015.

Andrea, V. J. \& Salovey, P. (2006). Peer Counselling: Skills, Ethics, and Perspectives (2 ${ }^{\text {nd }}$ Ed .). Palo Alto, Calif.: Science and Behavior Books.

Angela, O. (2014). Adolescent Social Development:Adolescents and Peer Pressure."Retrieved from http://www.sitemaker.umich.edu/ University of Michigan. on October 6, 2014.

Asatsa, S. \& Gichuho, M. C. (2014). An investigation in to the Batsotso Mourning Rituals in Kakamega County, Kenya. International Journal of Science and Research (IJSR) Vol.3 (9):794-79

Babbie, E. (2007). The Practice of Social Research. (12 ${ }^{\text {th }}$ Edition). USA: Chapman University.

Berk, L. E. (2009). Child Development. (8th ed). United States of America: Pearson Education, Inc.

Biener L. \& Siegel M. (2006). Adolescent Duress on Peer Death: more support for a causal inference. Washington D C, USAID Publication.

Bonanno, G A. (2006). 'Is Complicated Grief a Valid Construct?' Clinical Psychology: Science and Practice. Vol. 13 (2), 129-135.

Charmaz, K. (2006). Constructing a Wounded Adolescent Theory. A practical Guide Through Loss and Grief. London: Sage.

Cooney, E. (2010). "Puberty gap: Obesity splits boys, girls. Adolescent males at top of the BMI chart may be delayed". Retrieved from http://www.msnbc.com/id/35332881/ns/health-kids_and_parenting/ on 2013-05-22

Corcoran, K., Crusius, J. \& Mussweiler, T. (2011). Social comparison: Motives, standards, and mechanisms. In D. Chadee (Ed.), Theories in Social Psychology; (pp. 119-139). Oxford: Blackwell Publishing Ltd.

Corey G, (2005). Theory and Practice of Counseling Psychotherapy. (6th Ed) Pacific Groove: Brooks Cole.

Creswell, J. W. \& Plano-Clark, V. L. (2011). Designing and Conducting Mixed Methods Research (2nd ed.). Thousand Oaks, CA: Sage Publications.

Currie, J. \& Thiele, B. (2009). 'Globalization and Adolescence: Work and Culture in Societies'. In: A. Brooks, and A. Mackinnon, (Eds.): SRHE, Open University.

Deem, R. (2007). Adolescents Managing for Diversity in a Postmodern World. In: C. Marshall, (Ed.) Adolescent Critical Policy Analysis II: A Perspective from Post-Secondary Education. London: The Falmer Press.

Denzin, N. K., \& Lincoln, Y. S. (2011). The SAGE Handbook of qualitative research (4th Ed.). Los Angeles: Sage Publications.

Dorn L. D., Biro F. M. (2011). "Puberty and Its Measurement: A Decade in Review. Journal of Research on Adolescence; Vol. 21 (1), 180-195.

Doughty, E. D., Pfefferbaum, B., Pfefferbaum, R., Dumont, C. E., Pynoos, R. S., Gurwitch, R. S. \& Ndetei, D. (2006). Death studies: Trauma, Grief and Depression in Nairobi Children After the 1998 Bombing of the American Embassy. International Journal of social science:Vol. 30, (6) 561-577. DOI:10.1080/07481180600742566.

Dumontheil I., Apperly I.A. \& Blakemore S.J. (2009). Online usage of theory of mind continues to develop in late Adolescence. Developmental Science. Vol.13(2), 331-338.

Duncan, S. (2010). Grandma's philosophy: Progressive Language. Retrieved from http//www.justice.co.uk/grandma-s-philosophy on 20 th December, 2014.

Engler, (2008). Personality Theories: An Introduction. Cengage Learning. p. 151.ISBN 978-0-547-14834-2

Foa, E. B. (2011). Prolonged Exposure to Loss and Grief in Adolescents - Therapy for Post- Traumatic Stress Disorder: USA: Lyceum Books.

Forbes E.E., Phillips M.L., Ryan N.D., Dahl R.E. (2011). Neural systems of threat processing in adolescents: Role of pubertal maturation and relation to measures of negative affect. Developmental Neuropsychology.Vol. 36,429-452.

Forsyth, D. (2010). Group Dynamics. 5th Edition. Belmont, CA: Thomson Wadsworth.

Freeman, S. J. (2005). Grief \& Loss: Understanding the journey. Belmont, Calif.: Thomson Brooks/Cole.

Friedkin, N. E., \& Johnsen, E. C. (2011). Social Influence Network Theory: A Sociological Examination of Small Group Dynamics. Cambridge University Press. Retrieved from http://dx.doi.org/10.1017/CBO9780511976735 on 23rd November, 2014 
Genga, S. (2012). Healing through Grieving. Retrieved from http://www.standardmedia.co.ke/?articleID=2000070353\&story_title=KenyaHealing-through-grieving on November, $3^{\text {rd }} 2014$.

Graham G. (2005). Facing Death and the Life After. Waco, Tex: Word.

Grbac, S. (2008). How to implement a 'Peer Support' program in a P-6 School,"Scotch College Junior School, Melbourne Australia. International Boys' Schools Coalition 15th Annual Conference, Toronto, Canada.

Hoy, G. W. (2012). Life and Death among the Luo of Nyakach Plateau, Western Kenya. Grief perspectives Vol.3(3) pp19-23

http://www.globalgiving foundation.com/articles/adolescent-behavior-problems.html. Retrieved on 20th, November, 2011.

http://www.kisumuchildren.org.uk Retrieved on Thursday, 1st May, 2014

http://www.victorychurchesinternational.co.ke Retrieved on Friday, $2^{\text {nd }}$ May, 2014

Kamau, G. W. (2011). Adults' perspectives on loss and grief: A case study of Kiambu Municipality, Kenya.URI: Retrieved from http://irlibrary.ku.ac.ke/handle/123456789/2103 on 4th January, 2014.

Kinyua, R. (2014). Socio-cultural factors that inhibits entrepreneurship in Kenya-The Gender Question. Retrieved from http//www. popular.isbd.rhcloud.com on 30th January, 2015.

Kisumu Sub-County Education Office, (2013). Statistics on students on bursary and scholarships. Unpublished Circular. Kisumu subcounty office.

Klass, D., Silverman, P. R., \& Nickman, S. L. (2006). Continuing Bonds: New Understandings of Grief. Washington, DC: Taylor \& Francis. Kübler-Ross E. (1969). On Death and Dying. New York, NY: The Macmillan Co;.

Leek, O. L. (2011). "School-based Support Groups for Traumatized Students". School Psychology International. Vol. 32 (2), $163-178$.

Lucas, S. R. (2013). "Beyond the Existence Proof: Ontological Conditions, Epistemological Implications, and In-Depth Interview Research.", Quality \& Quantity. Vol 19 (7) 432-439. doi:10.1007/s11135-012-9775-3.

Macauley, C. Onyango, M. \& Niragira, E. (2012,). 'Peer-support Training for Nonliterate and Semiliterate Female Ex-combatants: Experience in Burundi,' Journal of ERW and Mine Action, Spring Vol. 16.(1),52-56.

Maree, J.G. (2012). Career Counselling in the $21^{\text {st }}$ century: Merging qualitative and quantitative approaches to facilitate 'best practice.' Special Issue of the Cypriot Journal of Educational Sciences, Vol.7 (1), 1-4

Mason, M. (2010). Sample Size and Saturation in PhD Studies Using Qualitative Interviews. Forum Qualitative Sozial for Schung I Forum: Qualitative Social Research, Vol. 11 (3), Art. Retrieved from http://www.nbn-resolving.de/urn:nbn:de:0114-fqs100387 on March 23'rd 2014 ,

Miesbach, D. (2013). From Grief to Joy. Retrieved from http://www.opentohope.com/from.grief.to.joy/ on March, $21^{\text {st }} 2014$.

Morgan, D. (2007). Paradigms Lost and Pragmatism Regained: Methodological Implications of Combining Qualitative and Quantitative Method. Journal of Mixed Methods Research; Vol1; 48 pp 52-59.DOI: 10.1177/2345678906292462 Retrieved from http://mmr. sagepub.com/cgi/content/abstract/1/1/48

Muchai L., Ngari S. \& Mumiukha C. (2014).The Influence of Perceived Post Election Violence on Emotional Well Being among Secondary School Students in Nakuru County, Kenya. International Journal of Innovative Research and Development Vol.3 (3) 126-135.

Mwiti, G. (2014). How is Kenya Coping - One year after Westgate Mall Attack? Retrieved from http//www.oasisafrica.kbo.co.ke on 13"th November, 2014.

Obrist, B. (2011). Multi-layered Social Resilience: a New Approach in Management of Socio-cultural Issues for Adolescents. Progress in Development Studies. Vol.10 (4) 283-293.

Okello, L. N. (2008). A Study of Adolescent Development Problems Among Girls in Secondary Schools. A case Study of Siaya and Kisumu Districts. Unpublished Master of Education Thesis: Kenyatta University.

Oso ,W.Y. \& Onen, D. (2009). Writing Research Proposal and Report. Nairobi: Sitima Press.

Owuor, B. W. \& Mauta, S. (2011). Strengthening Sustainable Adaptation: Examining interactions between Pastoral and Agropastoral Groups in Dryland Kenya. Climate and Development, Vol.3 (1), $42-58$.

Pelt, N. V. (2005). Heart to Heart-The Art of Communication. (11 ${ }^{\text {th }}$ Ed.), Houghton: Editorial Sufeliz.

Pomeroy, E. C., \& Garcia, R. B. (2011). Children and Loss: A Practical Handbook for Professionals. Chicago, III: Lyceum Books.

Punch, F.K. (2010). Introduction to Social Research: Quantitative and Qualitative Approaches. (2 ${ }^{\text {nd }}$ Edition). New Delhi: Sage Publications Ltd.

Rushkoff, D. (2005). Get Back in the Box : Innovation from the Inside Out. New York : Collins.

Sagoe, D. (2012). Precincts and prospects in the use of focus groups in social and behavioral science research. The Qualitative Report, Vol.17 (Art. 29), 1-16. Retrieved from http://www.nova.edu/ssss/QR/QR17/sagoe on 9th February, 2014.

Santrock, J.W. (2014). Life-Span Development. New York: McGraw-Hill Higher Education.

Scharf, M. \& Shulman, S. (2010). Adolescents' socio-emotional competence and parental representations of peer relationships in adolescence- A Paper presented at the Society for Research on Adolescence, Boston: Fireworks Press.

Valkenburg, P. M. \& Peter, J. (2011). Online Communication Among Adolescents: An Integrated Model of Its Attraction, Opportunities, and Risks.Journal of Adolescent Health, Vol.48 (2), 121-127.

Worden, J.N. (2005). Grief Counselling and Grief Therapy. (2nd Ed) Springer: Boston.

Ziv-Beiman, S. (2013). Therapist self-disclosure as an integrative intervention. Journal of Psychotherapy IntegrationVol.1 (23): $59-74$. doi:10.1037/a0031783 